\title{
PERBEDAAN EFEKTIVITAS PEMBERIAN JUS SEMANGKA DAN JUS APEL MANALAGI TERHADAP TEKANAN DARAH PADA MENOPAUSE PENDERITA HIPERTENSI
}

\author{
Nara Lintan Mega Puspita ${ }^{1}$, Rahma Kusuma Dewi ${ }^{2}$ \\ 1,2 Fakultas Ilmu Kesehatan Universitas Kadiri \\ Email : naralintan@unik-kediri.ac.id,rahmakusumadewi@unik-kediri.ac.id
}

\begin{abstract}
Abstrak
Penyakit hipertensi sering tanpa keluhan khas, hipertensi dengan komplikasi adalah salah satu penyebab utama kematian berbagai buah-buahan juga bisa menjadi alternatif untuk menurunkan tekanan darah seperti semangka, apel. Penelitian ini bertujuan untuk mengetahui perbedaan efektivitas jus semangka dan jus apel manalagi terhadap tekanan darah pada menopause penderita hipertensi di Puskesmas pembantu Badar Kidul Kota Kediri 2019. Metode penelitian ini adalah Quasi Eksperimen dengan rancangan Non Equivalent Control Group Design. Penelitian ini menggunakan instrument lembar lembar observasi dengan tensimeter, dengan purposive sampling diperoleh sampel 32 responden. Uji statistic Wilcoxon dan MannWithney. Hasil penelitian menunjukkan bahwa sebelum semangka $(81,2 \%)$, kriteria darah hipertensi adalah 13 responden, setelah diberi semangka (75\%), hipertensi kriteria normal (tinggi) adalah 12 responden. Sedangkan sebelum apel manalagi diberikan (sebagian besar 87,5\%) kriteria darah hipertensi adalah 14 responden ringan dan setelah apel diberikan sebagian besar $(56,2 \%)$ darah hipertensi kriteria normal 9 responden. Hasil analisis menunjukkan nilai $p$ value $=0,000<\alpha 0,05$ sehingga Ho ditolak, artinya ada perbedaan efektivitas jus semangka dan jus apel manalagi terhadap tekanan darah pada menopause penderita hipertensi di Puskesmas pembantu Badar Kidul Kota Kediri 2019. Pengobatan hipertensi dapat dilakukan secara rutin memeriksa kesehatan dan minum obat. Ada juga alternatif non farmakologi untuk menggunakan obat tradisional atau dengan berbagai jenis makanan atau buah-buahan yang dapat menurunkan tekanan darah. Diharapkan jus semangka dan jus apel merupakan salah satu buah yang dapat menurunkan tekanan darah pada penderita hipertensi.
\end{abstract}

Kata kunci: Jus Semangka, Jus Apel, Hipertensi, Menopause

\begin{abstract}
Hypertensive diseases are often without any typical complaints, hypertension with complications is one of the leading causes of death of various fruits can also be an alternative to lowering blood pressure such as watermelon, apples. This study aims to determine the differences in the effectiveness of watermelon juice and apple iuice Manalagi against blood pressure in menopause of hypertension sufferers at the Puskesmas helper Badar Kidul Kediri 2019. This research method is Quasi Eksperimen with design of Non Equivalent Control Group Design. This research use instrument sheet of observation sheet with tensimeter, with purposive sampling obtained sample 32 respondents. Wilcoxon and MannWithney statistics test. The result of the research showed that before the watermelon (81.2\%), the hypertensive blood criteria were 13 respondents, after being given watermelon $(75 \%)$, the hypertension of normal (high) criteria was 12 respondents. Whereas before apple was given (mostly $87.5 \%$ ) hypertension blood criteria was mild 14 respondents and after apple was given most $(56,2 \%)$ hypertension blood of normal criteria 9 respondents. The result analysis shows the value of $p$ value $=$ $0.000<\alpha 0.05$ so that Ho is rejected, meaning there is differences in the effectiveness of watermelon juice and apple juice Manalagi against blood pressure in menopause of hypertension sufferers at the
\end{abstract}


Puskesmas helper Badar Kidul Kediri 2019. Treatment of hypertension can be done routinely check health and take medicine. There is a nonfarmakologi therapy also an alternative to using traditional medicine or with various types of foods or fruits that can lower blood pressure. It is expected that apples and watermelon is a fruit that can lower blood pressure in people with hypertension.

Keywords : $\quad$ Watermelon Juice, Apple Juice, Hypertension, menopause

\section{LATAR BELAKANG}

Hipertensi merupakan masalah kesehatan yang umum terjadi di masyarakat. Banyak orang yang menderita penyakit tersebut, tetapi tidak menyadarinya. Penyakit ini berjalan terus seumur hidup dan sering tanpa adanya keluhan yang khas selama sebelum ada komplikasi pada organ tubuh Hipertensi merupakan penyakit degeneratif yang banyak diderita bukan hanya oleh usia lanjut saja, bahkan saat ini juga menyerang orang dewasa muda. Diketahui bahwa 9 dari 10 orang yang menderita hipertensi tidak dapat diidentifikasi penyebab penyakitnya (Anggraeni, 2012)

Berdasarkan data dari World Health Organization (WHO) tahun 2015, orang yang berusia diatas 50 tahun, tekanan darah sistolik lebih besar dari $140 \mathrm{mmHg}$ lebih beresiko terjadinya penyakit kardiovaskular bila dibandingkan dengan tekanan darah diastolik, namun pada tahun 2008 terdapat $40 \%$ orang dewasa diseluruh dunia berusia 25 tahun ke atas di diagnosa mengalami hipertensi. Angka kejadian hipertensi begitu meningkat, dari sekitar 600 juta jiwa pada tahun 1980 menjadi 1 milyar jiwa pada tahun 2008 (WHO, 2013). Data statistik terbaru menyatakan bahwa terdapat $24,7 \%$ penduduk Asia Tenggara dan 23,3\% penduduk Indonesia berusia 18 tahun ke atas mengalami hipertensi pada tahun 2014 (WHO, 2015).

Di tahun 2016 Survei Indikator Kesehatan Nasional (Sirkesnas) melihat angka tersebut meningkat jadi 32,4 persen. Ini berarti ada peningkatan sekitar tujuh persen. Angka hipertensi terus meningkat karena faktor risikonya di antara masyarakat juga terus meningkat mulai dari kebiasaan merokok, konsumsi garam, hingga minimnya buah dan sayur (Sirkesnas, 2016).

Data Dinas Kesehatan Kota Kediri menunjukkan bahwa Jumlah prevalensi penyakit Hipertensi Lansia di Kabupaten Kediri yang dilaporkan oleh puskesmas pada laki-laki adalah sebanyak 12.664 jiwa, sedangkan pada perempuan sebanyak 22.417 jiwa dan sebagian besar sudah memasuki menopause. 
Berdasarkan studi pendahuluan yang dilakukan di Puskesmas Campurejo Kota Kediri pada bulan Januari sampai dengan bulan Desember 2019 di Pustu Bandar Kidul sebanyak 1283 kunjungaan wanita menopause dan 420 orang yang mengalami hipertensi dengan prevalensi 32,6 \%. Pustu Bandar Kidul memiliki jumlah wanita menopause dengan hipertensi yang relatif tinggi (Puskesmas Campurejo, 2019).

Banyak faktor yang berpengaruh terhadap terjadinya hipertensi. Secara umum hipertensi disebabkan oleh faktor usia, stress, kurang berolahraga, kebiasaan merokok, kegemukan dan faktor turunan. Selain itu hipertensi juga terkait dengan faktor usia, jenis kelamin, menopause dan obesitas (Izumi, dkk 2007). Penyakit hipertensi berkembang pada seseorang yang mencapai usia separuh baya (antara usia 40 hingga 60 tahun). Hipertensi umumnya lebih banyak menyerang pria dan wanita pascamenopause yang diperkirakan sekitar $70 \%$ kasus baru penyakit hipertensi yaitu orang dewasa yang berat badannya sedang bertambah (Yuliarti, 2011).

Dampak dari penyakit hipertensi yang berkepanjangan menyebabkan perubahan patologis pembuluh darah dan hipertrofi ventrikel kiri. Perubahan menyebabkan hipertensi menjadi penyebab utama kejadian stroke, infiak miokard dan kematian mendadak akibat penyakit jantung. Selain kelemahan jantung, insuffisiensi ginjal dan aneurisma aorta disekans. Hipertensi merupakan faktor penyebab kematian dini terbesar ketiga di Indonesia.(Yuliarti, 2011).

Sebagai solusi dari permasalahan ini adalah masyarakat harus rutin periksa kesehatan dan minum obat. Selain itu juga ada alternatif dengan menggunakan obat tradisional atau dengan berbagai jenis makanan atau buah-buahan yang bisa menurunkan tekanan darah. Bagi negara tropis seperti Indonesia tanaman obat sangat mudah ditemukan maka obatobat alami dapat digunakan sebagai obat altematif untuk mengurangi efek samping dari bahan kimia yang terdapat pada obat-obatan. Selain itu buah-buahan juga dapat menjadi salah satu alternatif dalam menurunkan tekanan darah seperti Jus Semangka, Jus Apel. ( Anggraeni, 2012).

Solusi pengelolaan hipertensi dapat dilakukan menggunakan berbagai metode baik yang bersifat farmakologi maupun nonfarmakologi. Pengelolaan hipertensi secara farmakologi dapat dilakukan menggunakan obat modern yang bersifat kimiawi maupun pengobatan 
secara herbalis. Pengobatan secara herbal tergolong pengobatan komplementer merupakan suatu fenomena yang muncul saat ini diantara banyaknya fenomena pengobatan non konvensional yang lain, seperti pengobatan dengan ramuan atau terapi herbal, akupunktur, dan bekam. Pemanfaatan herbal merupakan salah satu 4lternative pengobatan yang dipilih masyarakat selain pengobatan secara konvensional/medis (Syaifuddin, 2013).

Buah Semangka dapat menurunkan tekanan darah pada penderita hipertensi. Semangka memiliki manfaat dalam menurunkan tekanan darah karena mengandung citirulline dan arginine, zat ini mampu merangsang produksi senyawa kimia yang membantu pembuluh darah menjadi lentur dan rileks. Semangka juga mengandung kalium $82 \mathrm{mg} / 100$ gram daging Buah Semangka. Kalium merupakan salah satu inhibitor pelepasan renin di ginjal. Kalium secara tidak langsung membantu perangsangan terhadap saraf simpatik dalam menghambat terjadinya retensi natrium sehingga menurunkan tekanan darah (Ma'mun, 2012). Selain itu apel (Pyrus mallus L.) merupakan salah satu buah-buahan yang telah lama dikenal masyarakat Indonesia. Selain rasanya enak apel juga rendah kalori, banyak mengandung serat. apel memiliki banyak manfaat untuk pengobatan. Salah satunya adalah menurunkan tekanan darah (Gheflati,2016). buah Apel merupakan salah satu buah yang mengandung kalium dalam jumlah cukup tinggi. Caranya dengan penambahan kalium pada menu makan, yaitu dengan menggunakan cuka apel yang telah diketahui kaya akan kalium (Nisa, 2013).

Mengingat permasalahan yang sudah dipaparkan di atas maka peneliti tertarik untuik mengadakan penelitian dengan merumuskan dalam judul penelitian "Perbedaan Efektivitas Pemberian Jus Semangka Dan Jus Apel Manalagi Terhadap Tekanan Darah Pada Menopause Penderita Hipertensi .

\section{METODE}

Penelitian ini menggunakan Quasi Eksperimen dengan rancangan Non Equivalent Control Group Design yang dilakukan dengan membagi responden menjadi 2 kelompok yaitu kelompok yang diberikan jus semangka dan kelompok yang diberikan jus apel manalagi. Penelitian ini yang dilakukan demgan cara melakukan pre test dahulu sebelum diberikan 
perlakuan. Setelah diberikan perlakuan, kemudian dilakukan post test. Penelitian ini menggunakan instrument lembar lembar observasi dengan tensimeter, dengan purposive sampling diperoleh sampel 32 responden. Uji statistic Wilcoxon dan MannWithney..

\section{HASIL DAN PEMBAHASAN}

Tabel 1 Distribusi Frekuensi Tekanan Darah Sebelum diberikan Jus Semangka dan Jus Apel Manalagi Pada Menopause Penderita Hipertensi Di Puskesmas Pembantu Bandar Kidul Kota Kediri 2019

\begin{tabular}{lcccc}
\hline \multirow{2}{*}{ Tekanan Darah } & \multicolumn{2}{c}{ Jus Semangka } & \multicolumn{2}{c}{ Jus Apel Manalagi } \\
\cline { 2 - 5 } & $\mathrm{F}$ & $\%$ & $\mathrm{~F}$ & $\%$ \\
\hline Normal & 0 & 0 & 0 & 0 \\
\hline Pra hipertensi & 0 & 0 & 0 & 87,5 \\
\hline Hipertensi Derajat I & 13 & 81,2 & 14 & 12,5 \\
\hline Hipertensi Derajat II & 3 & 18,8 & 2 & 100 \\
\hline Total & 16 & 100 & 16 & 0 \\
\hline
\end{tabular}

Berdasarakan tabel diatas didapatkan $13(81,2 \%)$ sebagian besar responden pada responden yang diberikan jus semangka dan 14 (87,5\%) sebagian besar responden yang diberikan jus apel manalagi keduanya menderita kriteria hipertensi derajat I.

Tebel 2 Tabel 1 Distribusi Frekuensi Tekanan Darah Sesudah diberikan Jus Semangka dan Jus Apel Manalagi Pada Menopause Penderita Hipertensi Di Puskesmas Pembantu Bandar Kidul Kota Kediri 2019

\begin{tabular}{lcccc}
\hline Tekanan Darah & \multicolumn{2}{c}{ Jus Semangka } & \multicolumn{2}{c}{ Jus Apel Manalagi } \\
\cline { 2 - 5 } & $\mathrm{F}$ & $\%$ & $\mathrm{~F}$ & $\%$ \\
\hline Normal & 0 & 0 & 0 & 0 \\
\hline Pra hipertensi & 0 & 0 & 0 & 0 \\
\hline Hipertensi Derajat I & 14 & 87,5 & 14 & 87,5 \\
\hline Hipertensi Derajat II & 2 & 12,5 & 2 & 12,5 \\
\hline Total & 16 & 100 & 16 & 100 \\
\hline
\end{tabular}

Berdasarkan Tabel diatas didapatkan 14 (87,5\%) sebagian besar responden pada responden yang diberikan jus semangka dan 14 (87,5\%) sebagian besar responden yang diberikan jus apel manalagi keduanya menderita kriteria hipertensi derajat I.

Tabel 3 Tabulasi Silang Tekanan Darah Sebelum dan Sesudah Diberikan Jus Semangka pada Menopouse Penderita Hipertensi Pada Menopause Penderita Hipertensi Di Puskesmas Pembantu Bandar Kidul Kota Kediri 2019 


\begin{tabular}{|c|c|c|c|c|c|c|c|}
\hline \multirow{3}{*}{$\begin{array}{c}\text { Kriteria Tekanan Darah } \\
\text { Hipertensi Sebelum } \\
\text { diberi Buah Semangka }\end{array}$} & \multicolumn{5}{|c|}{$\begin{array}{c}\text { Kriteria Tekanan Darah Hipertensi } \\
\text { Sesudah diberi Buah Semangka }\end{array}$} & \multirow{2}{*}{\multicolumn{2}{|c|}{ Total }} \\
\hline & Normal & \multicolumn{2}{|c|}{$\begin{array}{c}\text { Pra } \\
\text { hipertensi }\end{array}$} & \multicolumn{2}{|c|}{$\begin{array}{l}\text { Hipertensi } \\
\text { Derajat } 1\end{array}$} & & \\
\hline & F $\%$ & $\mathrm{~F}$ & $\%$ & $\mathrm{~F}$ & $\%$ & $\mathrm{~F}$ & $\%$ \\
\hline Hipertensi Derajat 1 & 212,5 & 10 & 62,5 & 1 & 6,2 & 13 & 81,2 \\
\hline Hipertensi Derajat 2 & 0 & 2 & 12,5 & 1 & 6,2 & 3 & 18,8 \\
\hline Jumlah & 212,5 & 12 & 75 & 2 & 12,5 & 16 & 100 \\
\hline
\end{tabular}

Berdasarkan tebel diatas yang terdapat pada tabel silang menunjukkan sebagian besar responden tekanan darah hipertensi sebelum diberi Jus Semangka kriteria hipertensi derajat 1 sebanyak 13 responden $(81,2 \%)$ dan setelah diberikan Jus Semangka kriteria prahipertensi sebanyak 12 responden $(75 \%)$ dengan tingkat signifikasi 0,000 yang artinya ada Pengaruh Jus Semangkan terhadap Tekanan Darah Hipertensi pada Menopouse.

Tabel 4 Tabulasi Silang Tekanan Darah Wanita Menopause Yang Menderita Hipertensi Sebelum dan Sesudah Diberikan Jus Apel Manalagi Pada Menopause Penderita Hipertensi Di Puskesmas Pembantu Bandar Kidul Kota Kediri 2019

\begin{tabular}{|c|c|c|c|c|c|c|c|c|}
\hline \multirow{3}{*}{$\begin{array}{c}\text { Kriteria Tekanan } \\
\text { Darah Hipertensi } \\
\text { Sebelum diberi Buah } \\
\text { Apel Manalagi }\end{array}$} & \multicolumn{6}{|c|}{$\begin{array}{l}\text { Kriteria Tekanan Darah Hipertensi } \\
\text { Sesudah diberi Buah Apel Manalagi }\end{array}$} & \multirow{2}{*}{\multicolumn{2}{|c|}{ Total }} \\
\hline & \multicolumn{2}{|c|}{ Normal } & \multicolumn{2}{|c|}{$\begin{array}{c}\text { Pra } \\
\text { hipertensi }\end{array}$} & \multicolumn{2}{|c|}{$\begin{array}{c}\text { Hipertensi } \\
\text { derajat } 1\end{array}$} & & \\
\hline & $\mathrm{F}$ & $\%$ & $\mathrm{~F}$ & $\%$ & $\mathrm{~F}$ & $\%$ & $\mathrm{~F}$ & $\%$ \\
\hline Hipertensi Derajat 1 & 8 & 50 & 6 & 37,5 & 0 & 0 & 14 & 87,5 \\
\hline Hipertensi Derajat 2 & 0 & 0 & 1 & 6,2 & 1 & 6,2 & 2 & 12,5 \\
\hline Jumlah & 8 & 50 & 7 & 43,8 & 1 & 6,2 & 16 & 100 \\
\hline
\end{tabular}

Berdasarkan tabel diatas menunjukkan sebagian besar responden tekanan darah hipertensi sebelum diberi Jus Semangka kriteria hipertensi derajat 1 sebanyak 14 responden $(87,5 \%)$ dan setelah diberikan Jus Apel manalagi kriteria normal sebanyak 8 responden (50\%). dengan tingkat signifikasi 0,000 yang artinya ada Pengaruh Jus Apel Manalagi terhadap Tekanan Darah Hipertensi pada Menopouse. 
Tabel 5 Effektifitas pemberian Jus Semangka dan Jus Apel Manalagi Pada Menopause Penderita Hipertensi Di Puskesmas Pembantu Bandar Kidul Kota Kediri 2019

\begin{tabular}{|c|c|c|c|c|}
\hline Variabel & $\mathrm{N}$ & $\begin{array}{c}\rho \\
\text { value }\end{array}$ & $\alpha$ & Kesimpulan \\
\hline $\begin{array}{l}\text { Kriteria tekanan darah } \\
\text { yang diberi Jus } \\
\text { Semangka - kriteria } \\
\text { tekanan darah diberikan } \\
\text { Jus Apel manalagi }\end{array}$ & 32 & 0.030 & 0.05 & $\begin{array}{c}\rho \text { value }= \\
0.000<\alpha= \\
0.05 \\
\text { (signifikan) }\end{array}$ \\
\hline
\end{tabular}

Hasil Analisis menggunakan uji MannWithney didapatkan $p$ value $=0,030<\alpha 0,05$ maka Ho di tolak dan H1 diterima artinya ada perbedaan tekanan darah diberikan Pemberian Jus Semangka Dan Jus Apel Manalagi Terhadap Tekanan Darah Pada Menopause Penderita Hipertensi

Hasil Analisis menggunakan uji MannWithney didapatkan $p$ value $=0,030<\alpha 0,05$ maka Ho di tolak dan H1 diterima artinya ada perbedaan efektivitas pemberian buah semangka dan buah apel manalagi terhadap tekanan darah pada wanita menopause penderita hipertensi di Pustu Bandar Kidul Wilayah Kerja Puskesmas Campurejo Kota Kediri Tahun 2018, dan berdasarkan tabulasi silang menunjukkan lebih efektif pemberian buah apel manalagi ketimbang semangka yaitu tekanan darah hipertensi diberi buah semangka kriteria normal 2 responden (12,5\%) sedangkan yang diberikan apel manalagi tekanan darah hipertensi kriteria normal 9 responden $(56,2 \%)$.

Hasil penelitian ini diperkuat dengan adanya penelitian yang dilakukan oleh Septyana (2014) dalam jurnalnya dinyatakan bahwa berdasarkan uji paired sample t-test pada jus buah apel hasil sistolik diperoleh p-value $(0,000)<0,05$ dan diastolik diperoleh $\mathrm{p}$-value $(0,010)<0,05$, dan pada jus buah melon sistolik diperoleh p-value $(0,000)<0,05$ dan diastolik diperoleh $p$-value $(0,007)<0,05$. Sehingga ada pengaruh pemberian jus buah apel dan melon terhadap tekanan darah pada lansia penderita hipertensi. Kemudian uji Independent t-test hasil yang didapat jus buah apel dan jus buah melon memiliki efektivitas yang sama terhadap tekanan darah yakni dari hasil perhitungan tekanan darah sistolik $\mathrm{p}=0,140$ dan tekanan darah diastolik didapatkan hasil $\mathrm{p}=0,492$. 
Hal senada juga diungkapkan Kinanti Z Ulfa (2016) dalam jurnal penelitiannya menunjukkan pengaruh tekanan darah sistolik pre test-posttest ditunjukkan dengan nilai $\mathrm{p}$ value 0,004 , diastolik dengan $\mathrm{p}$ value 0,038 . Adapun pada kelompok kontrol $\mathrm{p}$ value tekanan darah sistolik sebesar 0,014 , diastolik ,792. Nilai p value dari uji Wilcoxon $\mathrm{p}<0,05$, yang berarti ada perbedaan yang bermakna sebelum dan sesudah perlakuan pada tekanan darah sistolik dan diastolik. Uji Mann Whitney menunjukkan tidak ada perbedaan antara kelompok eksperimen dan kelompok kontrol pada selisih tekanan darah sistolik yang ditunjukkan dengan nilai $p$ value 0,165 dan diastolik $0,469, p>0,05$

Kandungan air, vitamin C, dan vitamin A (karotenoid), pada buah semangka dan buah apel manalagi juga sangat bermanfaat bagi kesehatan tubuh. Air merupakan komponen terbesar dalam tubuh sekitar 55\% sampai 75\% dari berat badan tubuh. Manfaat air yang berhubungan dengan tekanan darah adalah air sebagai pelarut dan membawa sampah hasil metabolisme tubuh sehingga natrium dapat dikeluarkan melalui air seni. Sedangkan vitamin $\mathrm{C}$ befungsi sebagai antioksidan yang berperan untuk mencegah dan mengobati kanker, peradangan dan penyakit jantung (Olivia, 2004 dalam Puspaningtyas, 2013). Vitamin $\mathrm{C}$ dapat memperkuat otot jantung dan vitamin $\mathrm{C}$ berperan penting melalui proses metabolisme kolesterol, karena dalam proses metabolisme kolesterol, vitamin $\mathrm{C}$ dapat meningkatkan laju kolesterol yang dibuang dalam bentuk asam empedu dan mengatur metabolisme kolesterol. Vitamin C juga dapat meningkatkan kadar HDL dan berfungsi sebagai pencahar sehingga dapat meningkatkan pembuangan kotoran (Kusuma, 2010).

Didapatkannya ada pengaruh tekanan darah diberikan buah semangka dan buah apel manalagi pada wanita menopause penderita hipertensi di Pustu Bandar Kidul Wilayah Kerja Puskesmas Campurejo Kota Kediri Tahun 2018, hal ini menurut pendapat peneliti bahwa pemberian buah semangka dan buah apel manalagi benar benar dapat menurunkan tekanan darah penderita hipertensi, dan dari kedua buah tersebut masing masing mempunyai keefektifan. Dari kedua buah tersebuat yang lebih efekktif menurunkan tekanan darah yaitu buah apel manalagi dibandingkan dengan buah semangka karena kandungan kaliumnya lebh tinggi dibanding buah semangka, hal ini terlihat jelas pada tabululasi silang yang dinyatakan hipertensi diberi buah semangka kriteria normal 2 responden sedangkan yang diberikan apel manalagi tekanan darah hipertensi kriteria 
normal 9 responden.

\section{KESIMPULAN DAN SARAN}

Ada perbedaan efektivitas pemberian Jus Semangka dan Jus Apel manalagi terhadap tekanan darah pada Menopause Penderita Hipertensi Di Puskesmas Pembantu Bandar Kidul Kota Kediri 2019. Di dalam penelitian ini yang lebih efektif untuk pmenurunkan hipertensi pada wanita menopause adalah Jus Semangka. Diharapakan penelitian ini dapat menjadi salah satu alternatif cara mencegah terjadinya hipertensi pada wanita menopause.

\section{UCAPAN TERIMAKASIH}

Terimakasih kepada semua yang membantu ,memberikan saran dan dukungan dari berbagai pihak, sehingga bisa terselesainya dalam mengerjkan penelitian ini. 


\section{DAFTAR PUSTAKA}

Anggreni. (2012). Hipertensi Pada Lanjut Usia. Jurnal Ners. No.2. Vol. 2. (Diakses Tanggal 20 Oktober 2017).

Antoni, DKK. (2013). Pengaruh Konsumsi Apel Terhadap Penurunan Kolesterol Darah Penderita Hipertensi di Dusun Pojok Desa Curah Malang Kecamatan Sumobito Jombang. Jurnal metabolisme vol.2 Jombang.

Arikunto, S. (2013). Prosedur Penelitan Suatu Pendekatan danPraktek Revisi V. Jakarta : Rineka Cipta

Atikah.(2014). Menopause. Yogyakarta :Numed

Balitbangkes. 2014. Penyebab Kematian Tertinggi di Indonesia tahun 2014. Jakarta : KEMENKES RI

Balitbangkes. 2013. Riset Kesehatan Dasar. Jakarta : KEMENKES RI

Bailey, S. J., Blackwell, J. R., Williams, E., Vanhatalo, A., Wylie, L. J., Winyard, P. G., \& Jones, A. M. (2016). Two weeks of watermelon juice supplementation improves nitric oxide bioavailability but not endurance exercise performance in humans. Nitric Oxide, 59, 10-20. doi:10.1016/j.niox.2016.06.008

Dinkes Kota Kediri. (2014). Profil Kesehatan Kota Kederi.

Depkes. 2014. Pusat Data dan Informasi Kementrian Kesehatan RI Hipertensi

Endang Purwoastuti\& Elisabet Siwi Walyani. (2015). Kesehatan Reproduksi dan Keluarga Berencana.Yogyakarta : Numed.

Fahimeh, DKK. (2015). Dietary Approaches to Stop Hypertension (DASH) Eating Plan : Beyond The Hypertension. Nutrition and Food Sciences Research Vol. 2. No. 1. Jan-Mar 2015. Page 3-10.

Gheflati, A., Bashiri, R., Kord, M. T., Ghadiri-Anari, A., Reza, J. Z., \& Nadjarzadeh, A. (2019). The effect of apple vinegar consumption on glycemic indices, blood pressure, oxidative stress, and homocysteine in patients with type 2 diabetes 
and dyslipidemia: A randomized controlled clinical trial. Clinical Nutrition ESPEN. doi:10.1016/j.clnesp.2019.06.006

Haryani, Ira. (2015). Menu Ampuh Atasi Hipertensi. Yogyakarta. Notebook.

Izumi, Y., Matsumoto, K., Ozawa, Y., Kasamaki, Y., Shinndo, A., Ohta, M.,Shimabukuro, H. (2007). Effect of Age at Menopause on Blood Pressure in Postmenopausal Women. American Journal of Hypertension, 20(10), 10451050. doi:10.1016/j.amjhyper.2007.04.019

Kholish, Nur. 2011. Bebas Hipertensi Seumur Hidup dengan Terapi Herbal. Yogyakarta : Real Books.

Kowalski, R.E. (2010). Terapi 8 Minggu Menurunkan Tekanan darah Tinggi dan Mengurangi Resiko Serangan Jantung dan stroke Secara Alami. Bandung: Qanita.

Lestari, E. P. (2011). Regulasi Tekanan Darah Pada penderita Hipertensi Primer Dengan Smoothie Pisang (Musa Paradisiaca). Jurnal Ners. No. 2. Vol. 6, 140-146

Lisnawati, E. (2010). Efektivitas Konsumsi Semangka Terhadap Tekanan Darah Tinggi Pada Usia Lanjut Penderita Hipertensi. Jurnal Ners. No.3. Vol.6/

Ma'mun. D., Nurcholis.(2012). Manfaat Jus Semangka. Jurnal No.1. Vol. 1.

Nisa, Intan. (2013). KhasiatSakitTanamanObatUntukDarahTinggi. Jakarta: NiagaSwadaya.

Ramayulis, Rita. (2013). Jus Super Ajaib. Jakarta: NiagaSwadaya.

Savitri, Dian. (2017). Diam-diam Mematikan, Cegah Asam Urat dan Hipertensi, Yogyakarta, Healthy.

Sholihah, Zuhriatun. (2015). Studi Komparast Pemberian Jus Semangka dan Melon Terhadap Tekanan Darah Pada Lansia Hipertensi di dusun Pundung Sleman Yogyakarta. Artikel Penelitian.

Syaifuddin Muh, 2013. Penggunaan Tanaman Herbal Pada Lansia Penderita Hipertensi Di Kecamatan Gatak Kabupaten Sukoharjo. Naskah Publikasi Fakultas Ilmu 
Kesehatan Universitas Muhammadiyah : Surakarta.

Tambayong, J. (2010). Patofisiologi untuk Keperawatan. Jakarta: BukuKedokteran EGC.

TaufanNugroho\& Bobby. (2014). Masalah Kesehatan Reproduksi Wanita. Yogyakarta :

Pustaka Baru Press

WHO. 2013. A Global Bref on Hypertension : Silent killer, global public healty crisis.

Wirakusuma, Emma. (2010). 202 Jus Buahdan Sayur. Jakarta : Penebar Swadaya. 